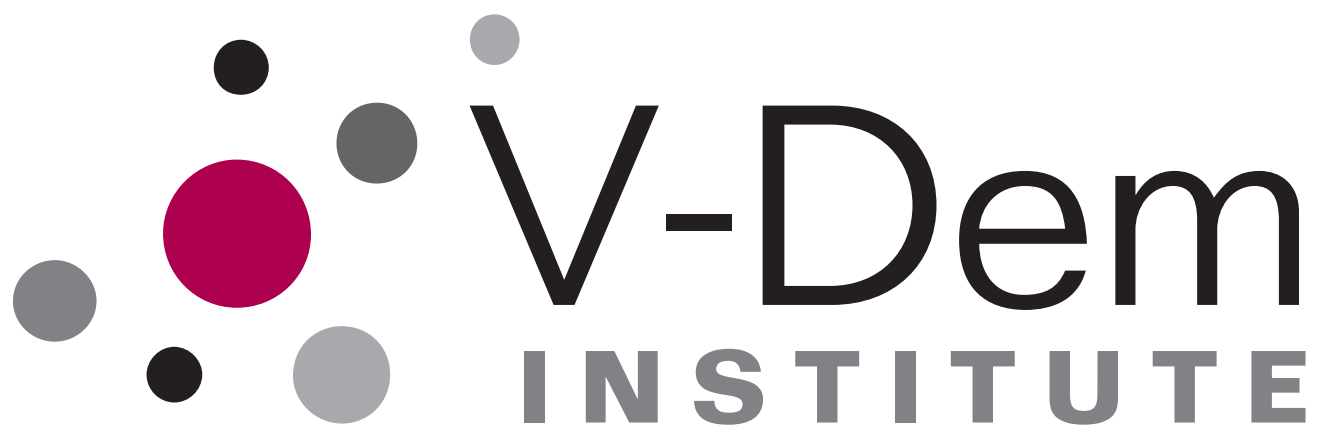

0000000000000000000 00000000000000000000000 0 0000000000000 -

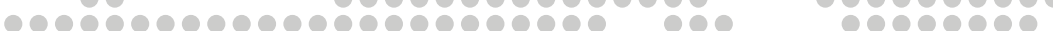

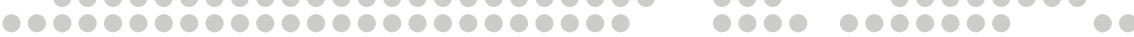

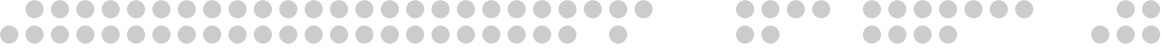

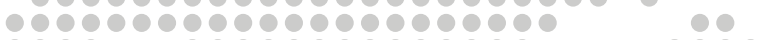

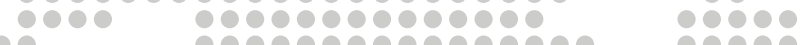

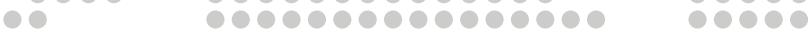
○००००000000000000 0000000

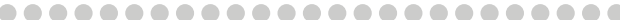

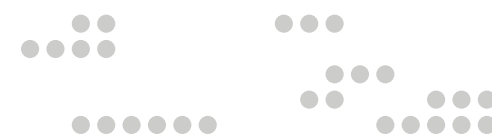

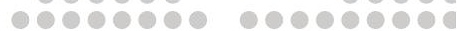

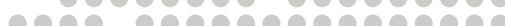

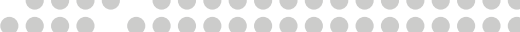

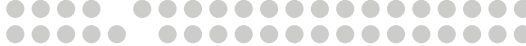

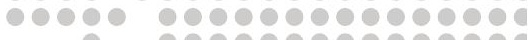
100000000000000000

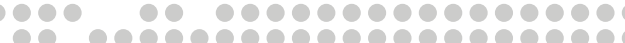
16809 ProO

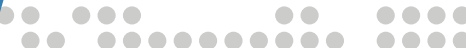

Vote Buying Is A Good Sign: Alternate Tactics of Fraud in Africa 1986-2012

Carolien van Ham Staffan I. Lindberg

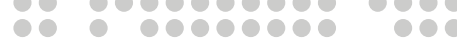

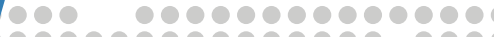
 bog00000000

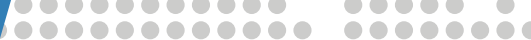

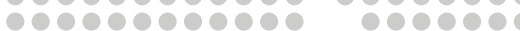

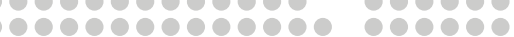

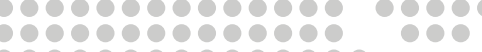

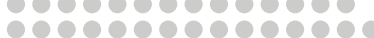

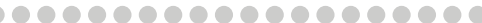

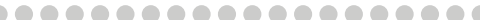
10800909090000000

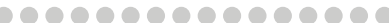
P0000000000000

6000000000090

0000000000

00000000000 1000000000

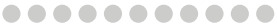

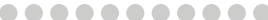
8 (1)
00000000

-

000000

100000

10000

000

000

10

10

O

0

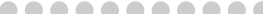
resereser -

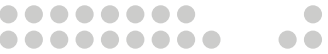
0000000 ○००0000

00000 1000 ○ी 
Varieties of Democracy (V-Dem) is a new approach to the conceptualization and measurement of democracy. It is co-hosted by the University of Gothenburg and University of Notre Dame. With a V-Dem Institute at University of Gothenburg that comprises almost ten staff members, and a project team across the world with four Principal Investigators, fifteen Project Managers, 30+ Regional Managers, 170 Country Coordinators, Research Assistants, and 2,500 Country Experts, the V-Dem project is one of the largest-ever social science research-oriented data collection programs.

Please address comments and/or queries for information to:

V-Dem Institute

Department of Political Science

University of Gothenburg

Sprängkullsgatan 19, PO Box 711

SE 40530 Gothenburg

Sweden

E-mail: contact@v-dem.net

V-Dem Working Papers are available in electronic format at www.v-dem.net.

Copyright (C) 2015 by authors. All rights reserved. 


\title{
Vote Buying Is A Good Sign: \\ Alternate Tactics of Fraud in Africa 1986-2012*
}

\author{
Carolien van Ham, \\ University of Gothenburg \\ Staffan I. Lindberg \\ University of Gothenburg
}

*This research project was supported by Riksbankens Jubileumsfond, Grant M13-0559:1, PI: Staffan I. Lindberg, V-Dem Institute, University of Gothenburg, Sweden; by Swedish Research Council, PI: Staffan I. Lindberg, V-Dem Institute, University of Gothenburg, Sweden \& Jan Teorell, Department of Political Science, Lund University, Sweden; and by Knut \& Alice Wallenberg Foundation to Wallenberg Academy Fellow Staffan I. Lindberg, V-Dem Institute, University of Gothenburg, Sweden. 


\begin{abstract}
Over 90 percent of the world's states currently select their national leaders through multi-party elections. However, in Africa the quality of elections still varies widely, ranging from elections plagued by violence and fraud to elections that are relatively "free and fair". The literature on election fraud and integrity has identified several factors explaining cross-national variation in overall levels of election integrity. Much less is known about trade offs between different strategies of electoral manipulation and the differences between incumbent and opposition actors' strategies. Existing research suggest that incumbents engage more in vote buying while opposition engage more in election violence. We theorize that choices for specific types of manipulation are driven by available resources and cost considerations for both incumbents and opposition actors, and are mutually responsive. We also suggest that costs of manipulative strategies are shaped by the level of democratization. We test our hypotheses on time-seriescross-section data for 285 African elections from 1986 to 2012. We find that democratization initially leads to increases in vote buying as "cheap" forms of electoral manipulation available to incumbents such as intimidation and manipulating electoral administration become less viable.
\end{abstract}




\section{Introduction}

In the wake of the third and fourth waves of democratization, elections spread around the world (Huntington 1991, Doorenspleet 2000). For all but a handful of countries, holding elections seems to have become a global norm: over 90 percent of the world's states now select their national leaders through multi-party elections (Global Commission 2012, Hyde 2011). However, the early optimism about this unprecedented development soon gave way to increasing skepticism. Observers noted that many of the newly democratizing regimes lacked basic guarantees of civil liberties and other aspects commonly considered as vital elements of democracy, such as institutions of horizontal accountability and enforcement of the rule of law (O’Donnell 1998, 2004; Diamond 2002; Rose and Shin 2001; Zakaria 1997).

Africa is no exception to this trend. About a quarter of all the world's states are found on the continent and it accordingly has produced a wide variety of political institutions and outcomes. While a number of countries in Africa held multi-party elections in conjunction with decolonization, by the end of the 1980s 42 out of 47 regimes in Africa were either closed autocracies that did not hold elections at all, or socialist regimes that held single-party elections. The end of the Cold War marked the start of a rapid transition. In just a few years, almost all the previously autocratic regimes started holding multi-party elections (Bratton and van de Walle 1997, Lindberg 2006). There was an outburst of optimistic scholarship voicing hopes for a 'second liberation' (e.g. Ayitteh 1992, Hyden and Bratton 1992) that soon turned into sour commentaries on the lack of 'real' change (e.g. Carothers 1997; Joseph 1998). The picture is in reality mixed, with some countries moving ahead and becoming more free (e.g. Ghana) while others drag their feet (e.g. Angola) or regress (e.g. Zimbabwe). The introduction of de jure multiparty elections in many African countries did not mark the "moment of transition to democracy", but rather indicated the starting point of slow, protracted transitions with uncertain outcomes.

Nevertheless, despite these setbacks, Lindberg $(2006,2009)$ notes that the introduction of multiparty elections did seem to influence the prospects for democratization. The analyses suggest that successive elections lead to subsequent increases in civil liberties, and as a consequence improve the overall quality of democracy as well. Likewise, we would expect the quality of elections, i.e. the degree to which elections are free and fair, to increase as successive elections are held. Van Ham (2012) finds that when taking all African regimes together, election quality 
indeed seems to increase as more elections are held. However, this aggregate trend hides substantial variation between countries. While in a range of countries, the quality of elections improves with successive elections, in others elections continue to be marred by irregularities and fraud. Hence, while almost all African nations currently hold multi-party elections, the quality of these elections varies widely, ranging from elections plagued by violence and fraud (like the Kenyan 2007 elections or the 2011 elections in DR Congo) to elections that were relatively "free and fair" (such as the 2008 elections in Ghana or the 2011 elections in Cape Verde).

Research on election fraud and electoral malpractice has identified several factors explaining cross-national variation in the quality of elections (Birch 2011, Donno 2013, Simpser 2013, Norris 2014). However, there are many different forms of electoral manipulation, and little is known about their use as possibly alternative strategies during democratization. This paper addresses that gap by mapping trends in the quality of African elections over time, and analyzing the trade-offs between different types of electoral manipulation. We argue that the choices for specific types of manipulation by either incumbent or opposition actors are driven by available resources and costs considerations. These are in turn shaped by the political and economic context in which elections take place. We further set out our theoretical framework and hypotheses in the next section.

The paper is set-up as follows. The next section presents our theoretical argument and hypotheses pertaining to trade-offs between different strategies to manipulate elections. The subsequent section provides descriptive statistics on the development of a select set of qualities of 285 African elections from 1986 to 2012, using the new Varieties of Democracy data (Coppedge et al. 2011, 2014). Section four discusses the data and methods used, followed by the results of our empirical analyses in section five. In the final section, we conclude and reflect on the implications of our findings for the future of democracy in Africa.

\section{Democratization and strategies of electoral manipulation}

Almost all modern definitions of democracy encapsulate Dahl's (1971) dictum that democracy is a political system in which government reflects the will of the people. It is well established that this requires not only popular participation but also competition (or, contestation as Dahl would have it). It is not uncommon to take as a starting point the Schumpeterian notion that identifies 
electoral competition as the minimal criterion of a democratic system. In other words, democracy is not only a "regime in which those who govern are selected through contested elections" (Przeworski et al 2000, 15; c.f. Przeworski and Limongi 1997, 178) but more importantly "democracy is a system of government in which parties lose elections" (Przeworski 1991, 10; c.f. Sartori 1987). For this to become reality, elections must first allow for multiple parties and candidates to compete, and second, they must be sufficiently free from manipulation to allow for de facto competition, resulting in alternation in power if citizens so desire.

Hence, elections must be multiparty and free from manipulation in order to function as "instruments of democracy" (Powell 2000). In representative democracy, elections function as a linkage mechanism between citizens and representatives, giving citizens the power to choose representatives to govern in their stead (Miller and Stokes 1963; Dahl 1989). The power of citizens to replace their representatives at elections, i.e. "throwing the rascals out", allows citizens to hold incumbents to account for their past performance, and at the same time creates incentives for representatives to be responsive to citizens' needs (Powell 2000; Przeworski, Stokes and Manin 1999, Strøm, Müller and Bergman 2003). So when elections function as 'instruments of democracy' they generate both accountability and responsiveness of governments vis a vis their citizens.

However, if elections are not multiparty and are manipulated, these functions are undermined. In elections that are not multiparty, there is no political opposition, and without political opposition there is no choice for citizens in elections. When there is no choice, the mechanism of vertical accountability breaks down, as citizens cannot vote for an alternative government if they are unsatisfied with the incumbents (Dahl, 1971, 1989; Hermet et al. 1978; Przeworski, Stokes \& Manin 1999). But even in multiparty elections, electoral manipulation can tilt the playing field to such an extent that the possibility of alternation is undermined, thereby limiting the power of citizens to hold their governments to account (and incentives for governments to be responsive to their needs). As noted by Huntington $(1991,174)$ the power to "throw the rascals out" is citizens' main weapon in the constant struggle to make sure that elected representatives are responsive. By removing or at least diminishing the threat of alternation, limits to multiparty competition in elections and electoral manipulation undermine the principle of vertical accountability, thereby undermining the main function of elections in democratic systems. 
Hence, the quality of elections is very important for democracy. However, elections are only one element of democracy, and other "partial regimes" such as civil liberties, rule of law and institutions of horizontal accountability are important features of democratic regimes as well (Schmitter and Karl 1991, Karl 1995, 2000, Diamond 1999, 2002). Following Schmitter (1992:427) we consider elections as "partial regimes" that form one component of "a composite of partial regimes" that together form a political regime. Democratization occurs when the quality of the overall regime, i.e. the composite of partial regimes, improves over time. ${ }^{1}$ The core argument we make in this paper is that democratization shapes the context in which elections take place, thereby shaping the incentive structure for political actors to engage in different strategies of electoral manipulation. ${ }^{2}$

The emerging literature on electoral manipulation has identified several factors explaining crossnational variation in overall levels of election integrity (Birch 2011, Van Ham 2012, Donno 2013, Simpser 2013, Norris 2014). Much less is known about trade offs between different strategies of electoral manipulation, nor about the differences between incumbent and opposition actors' manipulative strategies.

Elections are complex processes, and irregularities can occur at all the different stages of the electoral cycle: starting from the pre-election legal framework, registration and campaigning, to the actual voting on election day, to post-election vote counting, and the adjudication of results (Elklit and Reynolds 2005, Norris 2014). Hence, electoral manipulation can take many forms, ranging from voter and candidate intimidation, to manipulation of the electoral management body, to vote buying, and many more (Lehoucq 2003, Schedler 2002, Elklit and Reynolds 2005). ${ }^{3}$

\footnotetext{
${ }^{1}$ Note that the specific set of partial regimes that scholars consider necessary to define democracy differs, as democracy has different normative meanings and different empirical varieties (Collier and Levitsky 1997; Coppedge et al. 2011). Moreover, aggregate democratization as defined in this paper may occur in many different ways, as some partial regimes may improve in quality earlier than others. In this paper, we define democratization as the improvement in the overall level of democracy over time.

2 Of course, since elections are one of the partial regimes of which democracy consists, there is a risk of tautology here. The causal mechanisms that we theorize is that other partial regimes than elections, for example civil liberties and rule of law, improve in quality over time, and thereby shape the possibilities for political actors to engage in electoral manipulation. To prevent endogeneity, in our subsequent empirical analyses we use an aggregate measure of democracy that excludes the partial regime of elections.

${ }^{3}$ In the months before the election, aspects such as constituency and polling demarcation, party and voter registration, and campaign regulation are important for election integrity. Common irregularities in this phase are: gerrymandering, inaccurate voter registration lists, exclusion of opposition parties or candidates, unequal access to media and campaign resources, opposition intimidation, etc. During election-day, aspects such as access to polling stations, vote secrecy and access of election monitors are important. Examples of irregularities are lack of polling stations in rural areas, vote-buying and intimidation of voters, ballot-box stuffing, etc. Finally, after election-day important aspects are counting and tabulating the vote, resolving election related complaints, and publishing the election results. Here, problems that can occur are: biased counting of votes, not publishing disaggregate results, etc. (Elklit and Reynolds 2005, Calingaert 2006, Birch 2011). Clearly, elections are complex logistical operations, and
} 
In general, manipulative strategies aimed at candidates and voters can be classified along a continuum from more coercive to more co-opting strategies. One way to determine the outcome of elections is to intimidate voters and opposition candidates to such an extent that competition is reduced sufficiently for the incumbent to stay in power. Another way to undermine the integrity of an election is to engage in vote buying, 'persuading' voters with gifts and financial rewards. ${ }^{4}$ In addition to such sticks and carrots, a third strategy is to manipulate institutions, i.e. the legal framework and administration of elections. In this paper we argue first, that the choices for specific types of manipulation by either incumbent or opposition actors are driven by available resources and costs considerations, and second, that these costs are shaped by the political and economic context in which elections take place.

Actors engaging in electoral manipulation are likely to incur two types of costs: implementation and legitimacy costs (Birch 2011). Implementation costs are the financial and organizational resources needed to engage in manipulation, i.e. the costs to buy votes and organize brokers to approach and monitor potential vote 'sellers', the costs to organize party loyalists to help with intimidation of other candidates or voters, the costs to select and convince polling staff to stuff ballot boxes, bribe and/or co-opt judges, journalists and election officials, etc. While implementation costs are direct costs, legitimacy costs are potential costs that are only incurred if electoral manipulation were to be discovered. These costs can be quite high however. For example, if electoral manipulation is highly visible, the new incumbent(s) lacks domestic legitimacy which might lead to lower compliance with legislation by organizations and citizens, civilian protests and even armed rebellions or attempted coup d'etats (Norris et al. 2015). Obvious fraud might also affect international legitimacy, and possibly lead to political pressure and/or economic sanctions by international organizations and states. ${ }^{5}$ It follows that manipulative strategies that are more visible also increase the costs of manipulation. Hence, we

election integrity can be undermined at any step in the process, generating a large "menu of manipulation" that political actors can choose from (Norris 2014, Schedler 2002, Mozaffar and Schedler 2002).

${ }^{4}$ Vote buying is defined here as "the exchange of money, goods or services in exchange for votes" (Schaffer 2007:1). Vote buying can be considered as a dimension of clientelism, where clientelism refers to the broader nonprogrammatic distribution of public goods in return for political support (Stokes et al. 2013). Vote buying is distinct from patronage, as patronage is the provision of public sector employment in return for political support, while vote buying is the provision of a material reward in return for votes (Schaffer 2007; Stokes et al. 2013).

${ }^{5}$ Note that the degree to which legitimacy is of any concern to regimes might differ. For example, in the context of an electoral autocracy with a strong internal security apparatus compensating for lack of internal legitimacy towards citizens, and trade relations with predominantly other electoral autocracies that do not require legitimacy of government as a condition for trade, as in the case of DR Congo or ZImbabwe for example, the costs of electoral fraud, even if overt, can be limited, as the 2011 and 2013 elections respectively have shown. However, for most regimes in Africa, it seems safe to assume that some degree or at least semblance of legitimacy will be considered important, or at least preferable to none at all, and therefore perpetrators of electoral manipulation will prefer to keep their actions covert. 
expect that rational actors would prefer manipulative strategies that are cheaper (both in financial and organizational terms) and less visible; over more expensive and more visible strategies of manipulation. ${ }^{6}$

Following this logic we would expect the manipulation of institutions, i.e. the legal framework and administration of elections, to be the most cost-efficient and secure way to manipulate elections as it does not require financial resources and is generally less visible and less easy to detect than other forms of manipulation (Birch 2011). From the perspective of incumbents, manipulation of electoral laws and electoral administration hence seems the least costly option. Subsequently, intimidation is reasonably the second best option since it requires relatively few financial and organizational resources and is hence likely to be a "cheaper" form of manipulation than co-opting strategies such as vote buying (Bratton 2008, Collier and Vicente 2013). However, intimidation is typically more visible to voters and other domestic and international actors, and is therefore more likely to produce counter-reactions that may ultimately end up undermining regime legitimacy and stability. At a certain point, intimidation therefore places the incumbent in a dilemma where the costs of using it may be greater than the benefits (Schedler 2009). Finally, among the different electoral manipulation strategies, vote buying is probably the most costly form of manipulation and therefore should be the last resort for an incumbent. Vote buying requires substantial financial and organizational resources in order to affect the electoral outcome. $^{7}$ Detailed country case studies on vote buying have described how vote buying requires not only substantial financial resources, but also extensive local networks of brokers who can contact potential vote sellers and monitor compliance (Brusco, Nazareno, and Stokes 2004, Schaffer 2007, Stokes et al. 2013). ${ }^{8}$ Also, apart from financial and organizational costs, vote

\footnotetext{
${ }^{6}$ Note that, even if we expect both incumbents and opposition actors to base their choices on cost considerations, incumbent actors have an important advantage here. Incumbents have access to a wide range of manipulative strategies, while opposition actors' possibilities for manipulation are more limited. For example, incumbents have access to manipulate electoral laws and electoral administration, access to state resources and state media, etc. For opposition actors, possibilities to manipulate elections are much more limited, mainly to coercion and co-option of voters, rather than manipulation of institutions. We will further discuss this later in the paper.

${ }^{7}$ Estimates of the amount of money invested in vote buying vary from country to country. Schaffer (2007: 2) reports the price of a vote to range from about 60 cents in Manila to about 10.000 dollar in Kuwait. Compared to campaign costs in the US, it seems that vote-buying campaigns cost much more money per capita (relative to average incomes) in countries like Thailand and Uganda (Schaffer 2007: 189). In Africa, Lindberg (2003, 2010, 2012) finds that the cost of vote buying as a share of legislative candidates' salaries has gone up four-fold during democratization in Ghana and that the cost of an individual vote also increased significantly, making some candidates eventually seek other strategies.

${ }^{8}$ Historical research on vote buying demonstrates that "a market for votes only emerged when parties could monitor the behavior of voters and when they could not resort to intimidating citizens, manipulating the electoral registry, or manipulating the tally of the vote" (Lehoucq 2007: 37), and case studies on contemporary transitional democracies also suggest that vote buying tends to emerge only when other strategies of electoral manipulation are not feasible or cost-effective (Schaffer 2007: 191). Yet at the same time, vote buying is quite frequent, ranging from
} 
buying is typically illegal and quite easily detectable. Keefer \& Vlaicu (1997) posit that political clientelism is a strategy for politicians to gain repute, when it is lacking otherwise, which accords with our last resort argument here. Voters in Africa's emerging democracies are often assumed to respond to offers of clientelistic goods sometimes said to be distributed along ethnic lines (e.g. Burnell 2001; Nugent 2001; Posner 2005; Vicente and Wantchekon 2009). This logic is equivalent to accounts of how political parties provide private goods and policy favors primarily to groups who are receptive to material incentives (e.g. Lindbeck \& Weibull 1987; Persson \& Tabellini 2000). Therefore, it seems likely that vote buying will be targeted to specific groups of voters, and will not be used if other possibilities for manipulation exist. It seems unlikely that vote buying would be a preferred strategy as long as other possibilities for electoral manipulation are available.

We thus expect the choice for different manipulative strategies to depend on the costs associated with these respective strategies. This implies that cheaper methods of electoral manipulation, such as manipulation of electoral laws and administration as well as intimidation will be preferred to forms of manipulation that are more costly, such as vote buying. Hence, our first hypothesis refers to these trade offs between strategies of electoral manipulation:

\section{H1 - Vote buying increases as electoral administration manipulation and government intimidation decline}

However, the "menu of manipulation", i.e. the strategies of electoral manipulation that are available to actors, are likely to differ depending on the political and economic context in which elections take place, as well as on the type of actors involved in manipulation (Schedler 2002). For example, political actors will not be able to get away with manipulation of electoral laws and administration, or intimidation, in more developed democracies where independent media and judiciaries will denounce (and prosecute) such behavior. Manipulating electoral laws and administration may really only be a manipulative strategy available in electoral authoritarian regimes, where rule of law is weaker and the state bureaucracy is more vulnerable to partisan capture. Hence, we expect that democratization will lead to increases in vote buying as "cheap" forms of electoral manipulation available to incumbents such as intimidation and manipulating electoral administration become less viable. It is an empirical question to what degree 
development of democracy will subsequently lead to an eventual decline in vote buying as well, as elections become more free and fair. Thus, we hypothesize that:

H2 - Democratization leads to a decline in government intimidation and electoral administration manipulation and an increase in vote buying.

In a similar vein, we would expect that election violence is not a viable strategy for opposition actors in the most oppressive electoral autocracies, where election violence, or other forms of active dissent, are likely to be met with severe repression. Thus, we expect initial stages of democratization to be associated with an increase in election violence (Reif 2009; Norris et al. 2015). But at higher levels of democracy, we would expect the opposition strategy of using violence to affect the outcome of elections to become increasingly costly. When elections become more free and fair, using electoral violence should damage the opposition's credibility and weaken their position. Our intuition is that opposition parties realize this and should therefore actively size down their use of violence as democratization progresses further. Our final hypothesis hence refers to the consequences of democratization for strategies of elections violence as a curvilinear effect.

H3 - Democratization has a curvilinear relationship to election violence: an increase in violence as a consequence of initial democratization followed by a decline as the level of democracy increases further.

It is important to note that access to manipulative strategies tends to be unevenly distributed. While incumbents typically have access to a wide range of manipulative strategies, opposition parties' "menu of manipulation" (Schedler 2002) is more constrained. For example, incumbents can often manipulate electoral laws and the electoral administration, have access to state resources, and are more likely to be able to influence state media. Opposition actors' options are limited mainly to the use of illicit coercion and to the co-optation of voters but with less access to financial resources, thus often tilting their preferred strategy of manipulation towards coercion. Indeed it has been suggested in the case of Africa that incumbents engage more in vote buying while opposition engage more in election violence (Bratton 2008, Collier and Vicente 2013).

This does not mean that opposition actors necessarily engage in less electoral manipulation than incumbents. Evidence from international election observation missions in Africa suggest that 
agents of opposition parties were involved in attempts to steer elections towards their preferred outcome as well. ${ }^{9}$ However, incumbents have a larger menu of choice and typically larger resources available when it comes to manipulating elections. Thus, election administration manipulation, intimidation and to some extent vote buying can be thought of as more of government-dominated activities, while election violence may be the opposition's main choice of weapon, with the more costly vote-buying as a second-best option.

\section{The quality of elections in Africa}

Since the start of the third wave of democratization in 1974 and more markedly since the end of the Cold War in 1989, the number of countries in Africa that hold regular multi-party elections sharply increased (Figure 1). Whereas in 1974 only one country on the continent allowed for multiple parties and candidates, by 1980 the proportion of countries holding multi-party elections had risen to almost 20 percent. The largest leap occurred following the end of the Cold War. In only five years, the proportion of countries holding multi-party elections jumped from just 25 percent in 1988 to 84 percent in 1994. In 2012, virtually all African countries held multiparty elections for national offices (92 percent). ${ }^{10}$

\footnotetext{
${ }^{9}$ For example, in the 2011 DR Congo elections, one of the authors observed intimidation of pro-government supporters and opposition party observers in polling stations as well as polling station officials repeatedly "helping" voters to cast their votes in favor of opposition party candidates. Clearly, the incumbent political party in this election engaged in manipulation on much larger scale, and in many more ways than opposition did, however opposition actors certainly also engaged in electoral manipulation. As other examples, in the 2010 and 2011 presidential and legislative elections, the Carter Centre reported that both incumbent and opposition engaged in violence and intimidation: "Nor was the opposition free from such abuses. Both camps resorted to personal attacks, and their activists were involved in acts of violence or intimidation, which in some cases targeted the election observers." (p. 37). Likewise, in the 2007 elections in Kenya, the European Union observation mission observes instances of election violence initiated both by incumbent and opposition supporters.

${ }^{10}$ There are 4 countries that do not hold de jure multi-party elections yet, either because they just came into existence (South Sudan), or have experienced long periods of civil war (Eritrea, Somalia). The fourth country is Swaziland, where since 1993 the legislature is (partially) directly elected, but executive power still lies with the unelected monarch.
} 
Figure 1. The spread of multi-party elections in Africa

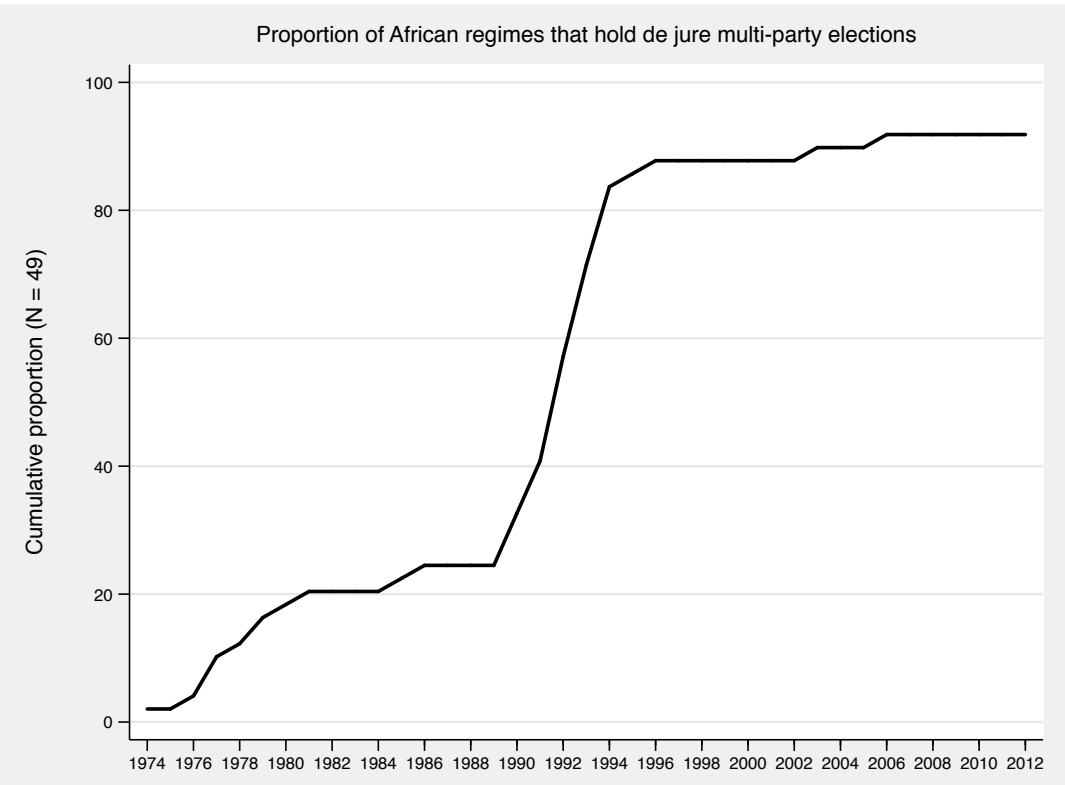

Source: Van Ham (2012).

In addition to the increasing number of countries holding elections, the number of successive elections within Africa's nations has increased substantially as well. As Table 1 shows, by 2012, more than 80 percent of these states have held 4 or more elections, and over 60 percent have held 6 or more elections.

Table 1. Number of national multi-party elections held per country (1986-2012).

\begin{tabular}{lll} 
Elections held $(\mathrm{N})$ & Countries $(\mathrm{N})$ & Percent of Countries \\
\hline 0 & 4 & 8.3 \\
3 & 4 & 8.3 \\
4 & 5 & 10.4 \\
5 & 6 & 12.5 \\
6 & 9 & 18.7 \\
7 & 6 & 12.5 \\
8 & 6 & 12.5 \\
9 & 2 & 4.2 \\
10 & 5 & 10.4 \\
11 & 1 & 2.1 \\
\hline Total & 48 & 100
\end{tabular}

Source: V-Dem Database, August 2014 (will be v2, November 2014). 
National elections include direct elections for the national legislature and

executive.

Yet, the quality of elections varies widely, ranging from elections plagued by violence and fraud, as the Kenyan 2007 elections or the 2011 elections in DR Congo, to elections that were essentially "free and fair", as the 2012 elections in Ghana or the 2011 elections in Cape Verde. Out of the 285 elections held on the subcontinent between 1986 and 2012, country experts evaluated 42 percent as substantively free and fair. ${ }^{11}$ The other elections were deemed either being "not at all" or "not really" free and fair (30 percent) or being of "ambiguous" quality (27 percent).

Figure 2 shows that the quality of elections in Africa has increased over time, yet even in 2012, a substantial proportion of elections still display problems that undermine the extent to which they can be considered free and fair. ${ }^{12}$

11 The Varieties of Democracy expert survey asked experts to evaluate for each election in their country of expertise:

"Taking all aspects of the pre-election period, election day, and the post-election process into account, would you consider this national election to be free and fair?" Answer categories where on a five-point scale, varying from 0 (no, not at all) to 4 (yes), with the following answer categories:

0: No, not at all. The elections were fundamentally flawed and the official results had little if anything to do with the 'will of the people' (i.e., who became president; or who won the legislative majority).

1: Not really. While the elections allowed for some competition, the irregularities in the end affected the outcome of the election (i.e., who became president; or who won the legislative majority).

2: Ambiguous. There was substantial competition and freedom of participation but there were also significant irregularities. It is hard to determine whether the irregularities affected the outcome or not (as defined above).

3: Yes, somewhat. There were deficiencies and some degree of fraud and irregularities but these did not in the end affect the outcome (as defined above).

4: Yes. There was some amount or human error and logistical restrictions but these were largely unintentional and without significant consequences.

12 Note that the "freeness" and "fairness" of elections represent two different dimensions of the quality of elections that may not always go together. As Elklit and Svensson (1997) outline "freedom entails the right and the opportunity to choose one thing over another" while "fairness involves both regularity (the unbiased application of rules) and reasonableness (the not-too-unequal-distribution of relevant resources among competitors)" (Elklit and Svensson 1997: 35). In terms of the specific strategies of electoral manipulation that we study in this paper, manipulating electoral administration most obviously undermines fairness, whereas vote buying and intimidation and violence are more clearly associated with freedom. However, these distinctions are not clear-cut, as intimidation and vote buying also tilt the level playing field in favor of actors with sufficient resources to engage in these forms of manipulation, thereby undermining fair competition. Likewise, manipulation of electoral administration also limits voters' freedom to send their incumbent government home if they are unsatisfied with it, thus also affecting the extent to which elections are free. Given the difficulty in separating these two dimensions, more recent conceptualisations of election quality and election integrity have focused rather on an electoral cycle approach, mapping electoral irregularities during the entire electoral cycle, from the period leading up to the election, to election day, to post-election (Elklit and Reynolds 2005, Norris 2014). See Van Ham 2014 for a discussion and overview of different conceptualizations of election integrity. In this paper, we use the experts' evaluation of both dimensions of election quality, asking them to evaluate both the free- and fair-ness of elections as a comprehensive measure of overall election quality. 
Figure 2. The quality of elections in Africa (1986-2012)

The quality of elections in Africa (1986-2012)

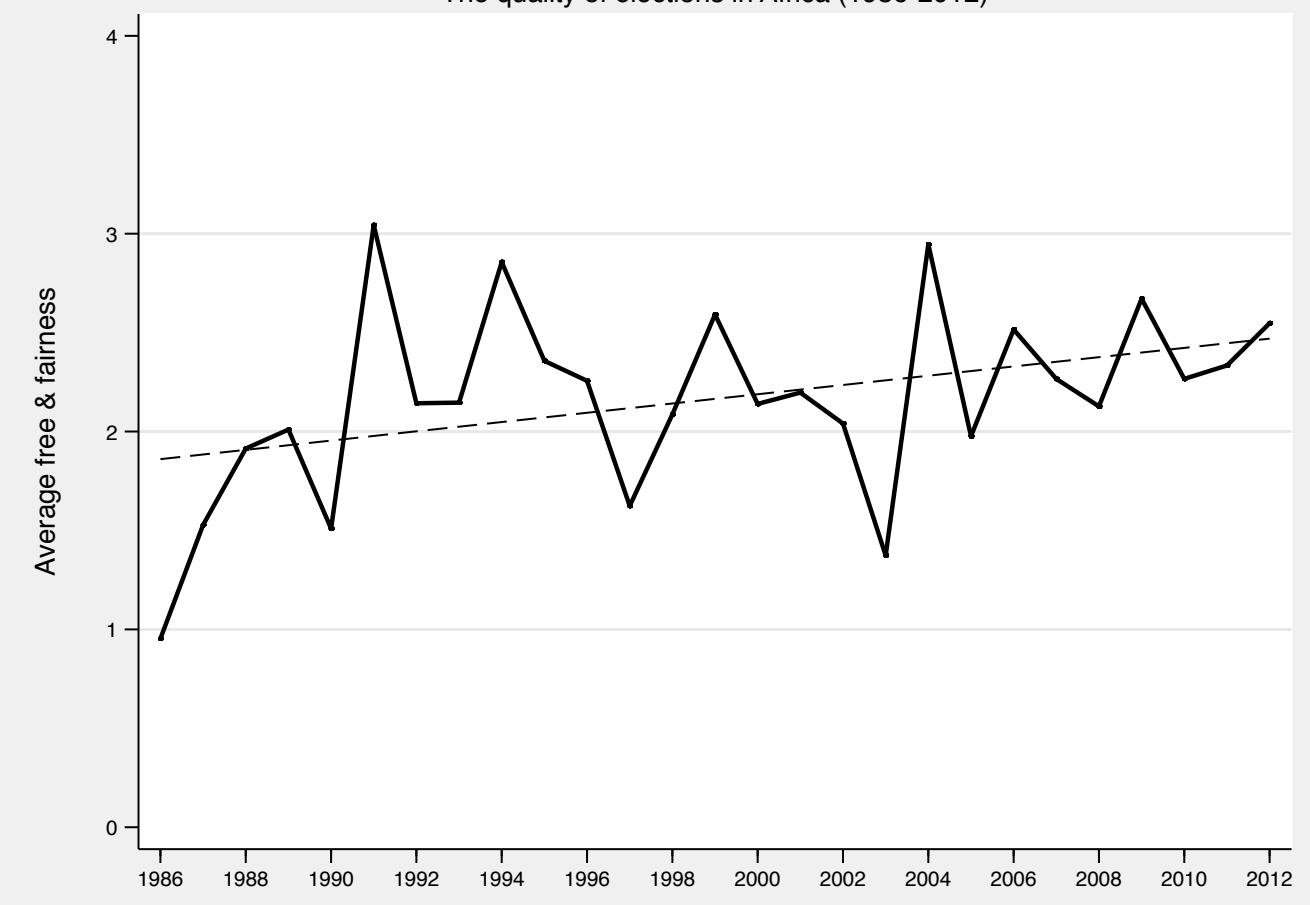

Source: V-Dem Database, August 2014 (will be v2, November 2014).

The Varieties of Democracy expert survey also asks experts to evaluate the presence of a number of specific irregularities and forms of manipulation occurring in elections. Figure 3 provides an overview of the types of irregularities and manipulation that occur most often in African elections. Surprisingly, while (non-government) election violence receives much attention in media coverage of African elections, experts judged only about 5 percent of elections to have serious problems with it, and slightly over 30 percent suffering from some amount election violence. Grave government intimidation also occurs in a minority of elections, though it is somewhat more frequent than election violence. 
Figure 3. Types of irregularities and manipulation in African elections (1986-2012)

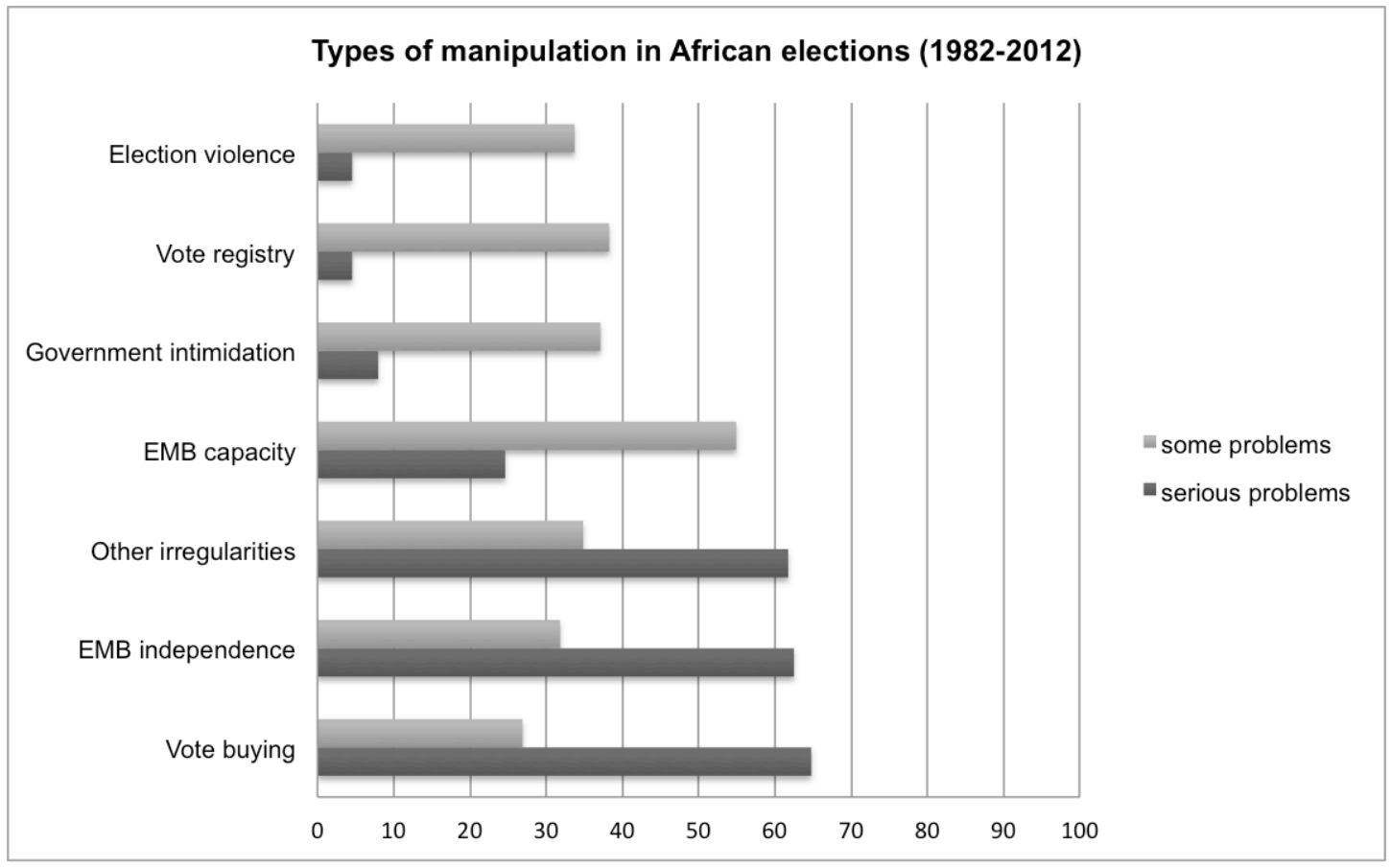

Source V-Dem Database, August 2014 (will be v2, November 2014).

Problems with the voter registry were also relatively uncommon. Severe problems occur in a small proportion of elections while about 40 percent of elections have some problems with their voter registries. This relative cleanliness may partly be the result of the intensive involvement of international election assistance in African elections, with much investment geared at improving civil and voter registries (Evrensel 2010). The problems with electoral management bodies' (EMB) capacity to organize elections are more recurrent: about 25 percent of elections displayed serious problems, and over 50 percent of elections faced some problems. This is perhaps not surprising considering the fact that elections are complex logistical operations that require substantial financial and organizational resources, both of which can pose considerable challenges in less developed countries. ${ }^{13}$

However, the most profuse problems signaled in African elections concern the political independence of electoral management bodies and the instances of vote buying. In over 60 percent of elections, experts flashed serious problems with the autonomy of the electoral management body from the government, and in over 30 percent of elections there were some

\footnotetext{
13 As an example, in the DR Congo 2011 elections, polling station materials and ballots had to be transported to the regional voting centers by airplane due to the limited road infrastructure in the country, and were frequently further transported to the further off rural polling stations by bike, boat or foot. Likewise, when the elections were over, many ballots had to be returned to regional counting centers in this way, often not escorted by police, and in many cases taking several days to arrive (Carter Centre 2011).
} 
problems with EMB autonomy. That leaves a small minority (10 percent) of elections without issues in this regard. Finally, vote buying appears to be the most common form of electoral manipulation in African elections: vote buying was a serious problem in about 65 percent of elections.

In conclusion, even if the quality of elections in Africa have improved overall, many of them continue to suffer from different types and varying levels of manipulation. ${ }^{14} \mathrm{~A}$ key question is how this variation can be explained, and under what conditions which sorts of transgressions are most likely to occur.

\section{Data and Methods for the Explanatory Analysis}

We test the three theoretical propositions using data from the Varieties of Democracy project. This is a new comprehensive dataset on democracy that collects data on almost 400 indicators of democracy in over 200 countries around the world from 1900 until 2012, engaging over 2,000 country experts worldwide to collect data (Coppedge et al. 2011, 2014). ${ }^{15}$ In this paper we use the V-Dem data on the quality of elections and strategies of electoral manipulation. Since very few de jure multi-party elections took place in Africa before 1986, we limit the period analysed to elections held between 1986 and 2012.

The V-Dem dataset includes data on the following types of electoral manipulation: electoral management body capacity, electoral management body autonomy, voter registry accuracy, vote buying, government intimidation, and election violence. ${ }^{16}$ To measure electoral management body capacity, experts were asked to evaluate: "Does the Election Management Body (EMB) have sufficient staff and resources to administer a well-run national election?”. Answers could be given on a 5-point scale varying from "No. There are glaring deficits in staff, financial, or other

\footnotetext{
${ }^{14}$ Note that the distinction between 'administrative irregularities' and 'intentional manipulation' is often made in research on electoral fraud and election integrity. Administrative irregularities often refer to problems with administrative capacity to organize elections, such as problems with voter registries and EMB capacity, and are often considered to be "unintentional", or at least not subject to intentional, partisan manipulation. However, while intuitively logical, in practice the line between intentional manipulation and administrative problems is often very difficult to draw, as even voter registries can be manipulated for political purposes (as Harris (2013) shows to be the case in Kenya), and EMBs can be deliberately starved for resources for political reasons, to mention just two examples (Van Ham 2014). Hence, in this paper we do not further use this distinction, and focus our theoretical account of trade-offs between types of irregularities on the assumption that these are all driven by intentional attempts at manipulating elections.

${ }^{15}$ For more information about the project, codebook and data, see: https://v-dem.net.

${ }^{16}$ A question was also asked on "other irregularities" that occurred in the election. However since this is a residual category including many different types of irregularities we don't include it in our analysis here.
} 
resources affecting the organization across the territory" to "Yes. The EMB has adequate staff and other resources to administer a well-run election". ${ }^{17}$ To measure electoral management body autonomy, experts were asked to evaluate: "Does the Election Management Body (EMB) have autonomy from government to apply election laws and administrative rules impartially in national elections?". Answers could be given on a 5-point scale varying from "No. The EMB is controlled by the incumbent government, the military, or other de facto ruling body." to "Yes. The EMB is autonomous and impartially applies elections laws and administrative rules." 18

To measure the accuracy of the voter registry, experts were asked to evaluate: "In this national election, was there a reasonably accurate voter registry in place and was it used?". Answer categories varied on a 5-point scale from "No. There was no registry, or the registry was not used" to "Yes. The voter registry was reasonably accurate (less than $1 \%$ of voters were affected by any flaws) and it was applied in a reasonable fashion". ${ }^{19}$

Vote buying in elections was measured by asking experts whether "In this national election, was there evidence of vote and/or turnout buying?". Again answers could vary along a 5-point scale

${ }^{17}$ EMB was defined as "whatever body (or bodies) is charged with administering national elections." The answer categories for electoral management body capacity are the following:

0: No. There are glaring deficits in staff, financial, or other resources affecting the organization across the territory.

1: Not really. Deficits are not glaring but they nonetheless seriously compromised the organization of administratively well-run elections in many parts of the country.

2: Ambiguous. There might be serious deficiencies compromising the organization of the election but it could also be a product of human errors and co-incidence or other factors outside the control of the EMB.

3: Mostly. There are partial deficits in resources but these are neither serious nor widespread.

4: Yes. The EMB has adequate staff and other resources to administer a well-run election.

18 The exact answer categories for electoral management body autonomy were:

0: No. The EMB is controlled by the incumbent government, the military, or other de facto ruling body.

1: Somewhat. The EMB has some autonomy on some issues but on critical issues that influence the outcome of elections, the EMB is partial to the de facto ruling body.

2: Ambiguous. The EMB has some autonomy but is also partial, and it is unclear to what extent this influences the outcome of the election.

3: Almost. The EMB has autonomy and acts impartially almost all the time. It may be influenced by the de facto ruling body in some minor ways that do not influence the outcome of elections.

4: Yes. The EMB is autonomous and impartially applies elections laws and administrative rules.

19 The exact answer categories for accuracy of the voting registry were:

0: No. There was no registry, or the registry was not used.

1: No. There was a registry but it was fundamentally flawed (meaning $20 \%$ or more of eligible voters could have been disenfranchised or the outcome could have been affected significantly by double-voting and impersonation).

2: Uncertain. There was a registry but it is unclear whether potential flaws in the registry had much impact on electoral outcomes.

3: Yes, somewhat. The registry was imperfect but less than $10 \%$ of eligible voters may have been disenfranchised, and double-voting and impersonation could not have affected the results significantly.

4: Yes. The voter registry was reasonably accurate (less than $1 \%$ of voters were affected by any flaws) and it was applied in a reasonable fashion. 
from "Yes. There was systematic, widespread, and almost nationwide vote/turnout buying by almost all parties and candidates." to "None. There was no evidence of vote/turnout buying.",20

Government intimidation was measured by asking experts: "In this national election, were opposition candidates/parties/campaign workers subjected to repression, intimidation, violence, or harassment by the government, the ruling party, or their agents?". Answer categories varied on a 5point scale from "Yes. The repression and intimidation by the government or its agents was so strong that the entire period was quiet." to "None. There was no harassment or intimidation of opposition by the government or its agents, during the election campaign period and polling day. ${ }^{21}$

Finally, opposition election violence was measured by asking experts: "In this national election, was the campaign period, election day, and post-election process free from other types (not by the government, the ruling party, or their agents) of violence related to the conduct of the election and the campaigns (but not conducted by the government and its agents)?" Answers varied on a 5-point scale from "No. There was widespread violence between civilians occurring throughout the election period, or in an intense period of more than a week and in large swaths of the country. It resulted in a large number of deaths or displaced refugees." to "Peaceful. No election-related violence between civilians occurred." ${ }^{22}$ Note that the election violence-indicator asks about

20 The exact answer categories for vote buying were:

0: Yes. There was systematic, widespread, and almost nationwide vote/turnout buying by almost all parties and candidates.

1: Yes, some. There were non-systematic but rather common vote-buying efforts, even if only in some parts of the country or by one or a few parties.

2: Restricted. Money and/or personal gifts were distributed by parties or candidates but these offerings were more about meeting an 'entry-ticket' expectation and less about actual vote choice or turnout, even if a smaller number of individuals may also be persuaded.

3: Almost none. There was limited use of money and personal gifts, or these attempts were limited to a few small areas of the country. In all, they probably affected less than a few percent of voters.

4: None. There was no evidence of vote/turnout buying.

${ }^{21}$ Note that other types of clearly distinguishable civil violence, even if politically motivated, during the election period were not included in the indicator for government intimidation. The exact answer categories were:

0 : Yes. The repression and intimidation by the government or its agents was so strong that the entire period was quiet.

1: Yes, frequent: There was systematic, frequent and violent harassment and intimidation of the opposition by the government or its agents during the election period.

2: Yes, some. There was periodic, not systematic, but possibly centrally coordinated - harassment and intimidation of the opposition by the government or its agents.

3: Restrained. There were sporadic instances of violent harassment and intimidation by the government or its agents, in at least one part of the country, and directed at only one or two local branches of opposition groups.

4: None. There was no harassment or intimidation of opposition by the government or its agents, during the election campaign period and polling day.

22 The exact answer categories for election violence were: 
violence related to the conduct of the election that was not conducted by the government, the ruling party, or their agents, and hence provides us with a measure of manipulation engaged in primarily by the opposition.

Since EMB capacity, EMB autonomy, and the accuracy of the voter registry are very highly correlated in the African elections, we combine these three measures into a single indicator of electoral administration manipulation by taking the average score on all three indicators for each election. ${ }^{23}$ This leaves us with four types of electoral manipulation to test the hypotheses: electoral administration manipulation, vote buying, government intimidation, and opposition violence. All variables were reversed so that higher scores indicate higher manipulation.

To measure the level of democratization we use various indicators available in the Quality of Government dataset (Teorell et al. 2013), testing the effects of the Polity IV democracy indicator, the Freedom House democracy indicator as well as the combined indicator of Polity IV and Freedom House developed by Hadenius and Teorell (2005). ${ }^{24}$

Apart from the level of democratization, some types of electoral manipulation are likely to be influenced by other contextual factors as well. As such, we would expect vote buying, but not other manipulative strategies, to be higher in countries with large proportions of poor citizens, as buying votes will be cheaper in these circumstances. In addition, we expect vote buying to be higher in countries that exploit natural resources, as this may provide incumbent governments with access to financial resources to fund vote buying. Finally, we expect the relative "costs" of election violence to be lower in countries that experienced civil war in the years preceding the elections. Demilitarization after civil war is difficult and almost never fully successful, increasing

No. There was widespread violence between civilians occurring throughout the election period, or in an intense period of more than a week and in large swaths of the country. It resulted in a large number of deaths or displaced refugees.

1: Not really. There were significant levels of violence but not throughout the election period or beyond limited parts of the country. A few people may have died as a result, and some people may have been forced to move temporarily.

2: Somewhat. There were some outbursts of limited violence for a day or two, and only in a small part of the country. The number of injured and otherwise affected was relatively small.

3: Almost. There were only a few instances of isolated violent acts, involving only a few people; no one died and very few were injured.

4: Peaceful. No election-related violence between civilians occurred.

23 The scale reliability coefficient of the three items is 0.862 .

${ }^{24}$ The results for vote buying, government intimidation, and election violence are essentially the same regardless of the democratization indicator used. However, for the election administration only the polity IV indicator could be used, as the other democratization indicators were too highly correlated to election administration manipulation in the current sample. Hence the models reported in table 2 and 3 include polity IV as democratization indicator. 
"easy" access of political factions to weapons that can be used at times of elections. Accordingly, we need to include controls in our analyses for these factors.

To measure poverty, we use data on GDP per capita from the World Development Indicators. However, since GDP per capita is not a very efficient indicator of poverty, particularly not for countries with large informal economies, we include an alternative indicator as well: average life expectancy from the World Development Indicators, taken from the Quality of Government dataset. Since it has also been argued that citizens in rural areas may be more vulnerable to electoral manipulation, we include an indicator for the proportion of the population that lives in rural areas (Birch 2011, Hicken 2007, Bratton 2008). To measure the degree to which incumbents may have access to state resources to finance electoral manipulation, we include a measure of the net oil exports per capita (Ross 2013). We include a dummy variable indicating whether the country was in a civil war at the time of the elections in order to control for this circumstance. ${ }^{25}$ The data were taken from Van Ham (2012) and updated by the present authors. Finally, we include type of election (legislative, executive, or concurrent) as control variable since executive elections should be the subject of greater attempts at manipulation in the many presidential regimes we find in Africa.

We analyze the data using time series cross-national analysis with fixed effects since we assume that choices of strategies of electoral manipulation are essentially driven by within country dynamics. As often occurs when analyzing developing democracies that made the transition to holding multi-party elections at different times, our panels are unbalanced, i.e. some countries have held more elections than others (see Table 1 for details). We test whether this affects our results by excluding countries that had held less than 5 elections as of 2012, and report the results of those analyses in the Appendix as well. The results do not change substantively, except for the hypothesized effect of democratization on election violence. In the models that restrict the analysis to countries having held at least 5 elections, we do find the expected curvilinear relationship between election violence and democratization.

\footnotetext{
${ }^{25} \mathrm{We}$ also tested the effect of a lagged variable indicating whether the country had experienced a civil war in the 2 years before the elections, however that did not turn out to be significant.
} 


\section{Results}

The results of the analyses are presented in Table 2. Models 1, 2, and 3 speak to hypothesis 1, positing that there is a trade-off between 'cheaper' strategies of manipulation like electoral administration manipulation and government intimidation and more costly strategies such as vote buying. The results show that we find such a trade off between manipulation of election administration and vote buying. As manipulation of the election administration declines, vote buying increases. The intuition here is that every incumbent would manipulate electoral administration if they could do so without incurring costs, hence, the actual decline in such manipulation indicates decreasing opportunities and increasing costs. Thus, it makes it rational for incumbents to turn to vote buying as an alternative strategy, which is also what the results demonstrate happens.

We do not find such a trade-off with government intimidation, however. It tends to vary in tandem with vote buying, suggesting that these two strategies are rather complementary than supplementary. Hence, our hypothesis 1 is partly confirmed and makes us rethink our theoretical assumptions to some extent. A perhaps likely possibility is that the costs of intimidation were overestimated in our reasoning.

Turning to hypothesis 2 about the consequences of democratization for the choice of manipulative strategy, Model 2 and 3 demonstrate that democratization is associated with a decline in the use of government intimidation and electoral administration manipulation. This corroborates the reasoning that these forms of manipulation simply become less viable as countries democratize.

Model 1 also substantiates that democratization is concomitant with an initial increase in vote buying. The squared indicator for democracy shows however, that as countries further democratize towards the highest levels of democracy vote buying becomes less viable as a manipulative technique and eventually declines. 
Table 2 - Explaining strategies of electoral manipulation in African elections (1986-2012)

$\begin{array}{llll}\text { Model 1 } & \text { Model 2 } & \text { Model 3 } & \text { Model 4 } \\ \text { Vote buying } & \text { Election } & \text { Government } & \text { Opposition } \\ & \text { administratio } & \text { intimidation } & \text { violence }\end{array}$

Trade-offs: other strategies of electoral manipulation

Vote buying (0-4)

n

Election administration manipulation (0-4)

Government intimidation (0-4)

Opposition violence (0-4)

Contextual effects: democratization

Polity IV (-10-+10)

Polity IV squared (0-100)

Contextual effects: economic development, poverty \& natural resources GDP per capita (current US\$, 120-12,156)

Life expectancy at birth (years, 37-74)

Rural population (\% of total population, $14-95$ )

Net oil exports value per capita (constant 2000\$, -180 - 3,232)

Contextual effects: civil war

Civil war in year of election? (0-1)

Control variable: type election ${ }^{\text {a }}$

Presidential
$-0.206^{*}$

$0.342 * * *$

$0.171 * *$

$0.028 * * *$

$-0.004 * *$

$-3.81 \mathrm{E}-05$

$-0.010$

$-0.007$

$1.56 \mathrm{E}-04$

$\begin{array}{lll}-0.125^{*} & 0.459^{* * *} & 0.178+\end{array}$

$0.805^{* * *} \quad 0.037$

$0.364 * * *$

$-0.068$

$0.315^{* *}$

$0.194 * *$

$-0.029 * * *$

$-0.014+$

0.001

0.002

0.001

$-0.002$

$-3.12 \mathrm{E}-05$

$-6.474 \mathrm{E}-08$

6.69E-05

0.004

0.004

0.004

$0.021 * * *$

$-0.019 *$

$0.026^{*}$

$9.45 \mathrm{E}-05$

6.34E-05

$-0.0005^{*}$

$0.355^{*}$

0.045

$-0.066$

$-0.007$

0.027 


\section{Concurrent}

Constant

R-squared (within)

$\mathrm{N}$ level 1 (elections)

$\mathrm{N}$ level 2 (countries)

$\begin{array}{llll}0.149 * & -0.087+ & -0.057 & 0.084 \\ 3.284^{* * *} & 0.270 & -0.446 & -1.488 \\ 0.44 & 0.61 & 0.51 & 0.28 \\ 246 & 246 & 246 & 212 \\ 42 & 42 & 42 & 42\end{array}$

Time series cross-section analyses, fixed effects. P-values: $+0.1, * 0.05, * * 0.01, * * * 0.001$ (two-sided). a. Legislative is reference category 
This is an unexpected result from the point of the theoretical reasoning above yet it makes intuitive sense. At the lower levels of democracy, steps towards greater democratization make the alternative strategies of manipulation less viable and the more costly strategy of vote buying emerges as it increasingly become the most viable mechanism to affect the outcome of an election. At a certain locus (for our sample this is estimated to be at between 5 and 6 on the Polity2 20-point scale), there is a breaking point when vote buying decreases in utility.

This seems intuitive if one considers what happens at these levels of democracy. Voters become more and more sophisticated and also gain experience with elections and start monitoring what incumbents have done in office. Institutions of the state, judiciary, and election administration gain additional autonomy and increasingly gain capacity to impose sanctions on illicit actions of this nature. The media becomes more independent and professionalized and will report cases of illicit activities that threaten to cost candidates more votes than are gained by vote-buying, and policy goals rather than immediate gratification in terms of small gifts gain more traction. In the end, we should expect vote buying to decrease as a consequence of moving from the middle to the highest end of a democratization scale.

Model 4 demonstrates that the expected curvilinear dynamic occurs for election violence too, however the results do not reach conventional levels of statistical significance. We can thus not reject the null hypothesis regarding our third proposition about the consequences of democratization for election violence when it comes to the sample of elections in Africa. The finding that this effect does become significant when analyzing only countries that have held a minimum of 5 elections suggests that future research with a larger sample (more years and therefore elections in Africa and/or a global sample), may corroborate the hypothesis.

Regarding the controls, Model 1 illustrates that vote buying is higher in countries with higher levels of poverty, as both GDP per capita and life expectancy is negatively related to the extent of vote buying (though only the latter reaches statistical significance). The proportion of citizens living in rural areas does not appear to significantly affect the level of vote buying. Finally, oil exports have the expected effect on vote buying: in countries that have higher net oil exports vote buying is substantially higher. Along the theoretical 
propositions above, the economic variables are generally not related to other types of electoral manipulation. Finally, we also find as expected that civil war increases the propensity of election violence substantially. The results thus confirm the importance of including the control for civil war in order to isolate the incidences of election violence that occurs as part of an ongoing civil war from election violence that is purely related to the election.

\section{Conclusions and Reflections}

This paper is one of few academic efforts so far trying to disentangle varying strategies for the manipulation of elections, with a focus on less developed countries on the African subcontinent, and to evaluate a first set of theoretical propositions in the framework of democratization.

The results largely support the theory. An incumbent's strategies of government intimidation and manipulation of the electoral administration seems to go from being the first hand choice of more dictatorial rulers in electoral authoritarian regimes, to become less and less attractive tools to stay in power as countries democratize. Vote-buying conversely increases with democratization and becomes more and more pervasive as the level of democracy rises, as predicted by the theory. However, we find that when countries approach the highest echelons of democracy, vote-buying again becomes less attractive as a means to win elections.

What we theorized to be the main form of manipulation available to the opposition election violence - displays the expected curvilinear relationship to democratization: It becomes more prevalent during democratization but decreases again with moves from an upper-mid level of democracy to the highest strata. Controlling for contexts where we expect exogenous circumstances in the form of civil war to peak violence around elections, these effects remain.

We think these findings put us in a position to indicate a few things that are relevant for the future of democracy in Africa. More than half of the countries on the subcontinent are still at what we may consider the "lower half" of the democratization scale. For these countries, the future will hold elections where the administration of elections becomes 
better and better but at the same time other illicit activities such as vote-buying will increase. Not all things go together, at least not all the time. The future of democracy in Africa will mean more money in politics, more patronage and clientelistic offers thrown around, and for a while increasing use of violence as a strategy to influence the outcome. And we should remind the reader, this is violence primarily perpetuated by opposition parties and their agents. They are not necessarily always good-minded, "pure" democrats at heart.

While the global trend towards increasing democracy has stalled, and some say it has even reversed, the trend in Africa is still positive. It is true that the subcontinent was far behind the world in the early 1990s and therefore it is perhaps not surprising that relative improvements have been on a greater scale there than anywhere else (save perhaps Eastern Europe). This may also contribute to Africa still gradually moving, on average, towards more democracy while the world as a whole has stalled. Yet, there is a cautionary note to be issued in this respect. If the above is true, we should perhaps expect the developments towards greater democracy stall in Africa as well soon, if the subcontinent follows the general pattern.

In addition, we cannot help notice that in many respects the now still more harshly authoritarian regimes in Africa also seem to be the "hardest nuts to crack" if the reader allows for the expression. War-scarred countries like the two Sudans, Central African Republic, and Somalia, resource-rich and repressive states like Equatorial Guinea and Angola, and ruthless dictatorships like Eritrea and Zimbabwe. For democracy to make substantial gains in the nearer future in these and other similar countries, something more than just repeating elections is naturally needed. 


\section{References}

Ayittey, G. (1992) Africa Betrayed. New York: St. Martin's Press.

Birch, S. (2011) Electoral Malpractice. New York: Oxford University Press.

Bratton, M. (2008) Vote buying and violence in Nigerian election campaigns. Electoral Studies, 27:621-632.

Bratton, M. and Van de Walle, N. (1997) Democratic Experiments in Africa: Regime Transitions in a Comparative Perspective. Cambridge: Cambridge University Press.

Burnell, P. (2001) The Party System and Party Politics in Zambia: Continuities Past, Present and Future. African Affairs, 100(399): 239-263.

Carothers, T. (1997) Democracy without Illusions. Foreign Affairs 76: 85-99.

Collier, P. and Vicente, P.C. (2013) Votes and Violence: Evidence from a Field Experiment in Nigeria. The Economic Journal, 124: 327-355.

Coppedge, M., Gerring, J., Altman, D., Bernhard, M., Fish, S., Hicken, A., Kroenig, M., Lindberg, S., McMann, K., Paxton, P., Semetko, H., Skaaning, S., Staton, J. \& Teorell, J. (2011). Conceptualizing and Measuring Democracy: A New Approach. Perspectives on Politics, 9(2):247-267.

Coppedge, Michael, John Gerring, Staffan I. Lindberg, Jan Teorell, David Altman, Michael Bernhard, M. Steven Fish, Adam Glynn, Allen Hicken, Carl Henrik Knutsen, Matthew Kroenig, Kelly McMann, Daniel Pemstein, Megan Reif, Svend-Erik Skaaning, Jeffrey Staton, Eitan Tzelgov, Yi-ting Wang. 2014. "Varieties of Democracy Codebook v1”. Varieties of Democracy Project: Project Documentation Paper Series.

Dahl, R. A. (1971) Polyarchy: participation and opposition. New Haven: Yale University Press.

Dahl, R. A. (1989) Democracy and its critics. New Haven: Yale University Press.

Diamond, L. (2002) Elections without democracy: Thinking about hybrid regimes. Journal of Democracy, 13(2): 21-35.

Donno, D. (2013) Defending Democratic Norms. International Actors and the Politics of Electoral Misconduct. Oxford: Oxford University Press.

Doorenspleet, R. (2000) Reassessing the Three Waves of Democratization. World Politics, 52(3): 384-406.

Elklit, J., and Reynolds, A. (2005) A Framework for the Systematic Study of Election Quality. Democratization 12(2): 147-162.

Evrensel, A. (ed.) (2010) Voter Registration in Africa: A Comparative Analysis. Johannesburg: EISA. 
Global Commission on Elections, Democracy and Security. (2012) Deepening Democracy: A Strategy for Improving the Integrity of Elections Worldwide. Report of the Global Commission on Elections, Democracy and Security.

Hadenius, A. and Teorell, J. (2005) “Assessing Alternative Indices of Democracy." In: Committee on Concepts and Methods - Working Paper Series.

Hermet, G., Rose, R., Rouquie, A. (Ed.). (1978) Elections without choice. New York: Macmillan.

Hicken, A. D. (2007) How Do Rules and Institutions Encourage Vote Buying? . In F. C. Schaffer (Ed.), Elections for Sale: The Causes and Consequences of Vote Buying. Boulder: Lynne Rienner Publishers.

Huntington, S.P. (1991) The third wave: democratization in the late twentieth century. Norman: University of Oklahoma Press.

Hyde, S.D. (2011) Catch Us If You Can: Election Monitoring and International Norm Diffusion. American Journal of Political Science 55(2): 356-369.

Hyden, G. and Bratton, M. (eds.) (1992) Governance and Politics in Africa. Boulder CO: Lynne Rienner.

Jospeh, R. (1998) Africa, 1990-1997: From Abertura to Closure. Journal of Democracy 9(2): 3-17.

Keefer, P. and Vlaicu, R. (1997) “Democracy, credibility and clientelism.” Washington, DC: World Bank, Policy Research Working Paper No. 3472.

Lehoucq, F. (2003) Electoral Fraud: Causes, Types, and Consequences. Annual Review of Political Science, 6: 233-256.

Lindbeck, A. and Weibull, J. W. (1987) Balanced-budget redistribution as the outcome of political competition, Public Choice 52: 273-97.

Lindberg, S. (2003) It's our time to "chop": do elections in Africa feed neopatrimonialism rather than counter-act it?, Democratization 14(2): 121-40.

Lindberg, S. (2010) What Accountability Pressures Do MPs in Africa Face and How Do They Respond? Evidence from Ghana, Journal of Modern African Studies 48(1).

Lindberg, S. (2006) Democracy and Elections in Africa. Baltimore: Johns Hopkins University Press.

Lindberg, S. (Ed.). (2009) Democratization by Elections. A New Mode of Transition. Baltimore: John Hopkins University Press.

Norris, P. (2014) Wby Electoral Integrity Matters. New York: Cambridge University Press. 
Nugent, P. (2001) Winners, Losers, and Also Rans: Money, Moral Authority, and Voting Patterns in the Ghana 2000 Election, African Affairs 100(400): 405-428.

O'Donnell, G.A. (1998) Horizontal Accountability in New Democracies. Journal of Democracy, 9(3): 112-126.

O'Donnell, G.A. (2004) Why the Rule of Law Matters. Journal of Democracy, 15(4): 32-46.

Persson, T. and Tabellini, G. (2000) Political Economics: Explaining Economic Policy. Cambridge: MIT Press.

Posner, D. (2005) Institutions and Ethnic Politics in Africa. Cambridge University Press.

Przeworski, A., Alvarez, M., Cheibub, J.A. and Limongi, F. (2000) Democracy and Development: Political Institutions and Well-Being in the World, 1950-1990. Cambridge: Cambridge University Press.

Przeworski, A., Stokes, S.C., Manin, B (Ed.). (1999) Democracy, accountability, and representation. New York: Cambridge University Press.

Przeworski, A., and Limongi, F. (1997) Modernization: Theories and Facts. World Politics, 49(2): 155-183.

Przeworski, A. (1991) Democracy and the Market. Cambridge: Cambridge University Press.

Rose, R. and Shin, C.D. (2001) Democratization Backwards: The Problem of ThirdWave Democracies. British Journal of Political Science, 31(2): 331-354.

Ross, M. L., 2013-02, "Oil and Gas Data, 1932-2011", http://hdl.handle.net/1902.1/20369 UNF:5:dc22RIDasveOTAJvwIjBTA== V2.

Sartori, G. (1987) The theory of democracy revisited. Chatham N.J.: Chatham House Publishers.

Schaffer, F.C. (Ed.). (2007) Elections For Sale. The Causes and Consequences of Vote Buying. London: Lynne Rienner Publishers.

Schedler, A. (2009) Electoral authoritarianism. In: The SAGE Handbook of Comparative Politics, 381.

Schedler, A. (2002) The Menu of Manipulation. Journal of Democracy, 13(2): 36-50.

Simpser, A. (2013) Why Governments and Parties Manipulate Elections: Theory, Practice, and Implications. Cambridge: Cambridge University Press.

Teorell, J., Charron, N., Dahlberg, S., Holmberg, S., Rothstein, B., Sundin, P. and Svensson, R. (2013) The Quality of Government Dataset, version 15May13. University of Gothenburg: The Quality of Government Institute, http://www.qog.pol.gu.se. 
Van Ham, C. (2014) Getting elections right? Measuring electoral integrity. Democratization. DOI: $10.1080 / 13510347.2013 .877447$.

Van Ham, C. (2012) "Beyond Electoralism? Electoral fraud in third wave regimes 19742009.” PhD diss. European University Institute.

Vicente, P. and Wantchekon, L. (2009) Clientelism and vote buying: lessons from field experiments in African elections. Oxford Review of Economic Policy, 25(2): 292-305.

Zakaria, F. (1997) The rise of illiberal democracy. Foreign Affairs, 76: 22-41. 


\section{Appendix}

Table 3 - Explaining strategies of electoral manipulation in African elections (1986-2012) - Robustness checks (countries with T > 4 elections)

Trade-offs: other strategies of electoral manipulation

Vote buying (0-4)

Election administration manipulation (0-4)

Government intimidation (0-4)

Opposition violence (0-4)

Contextual effects: democratization

Polity IV $(-10-+10)$

Polity IV squared (0-100)

Contextual effects: economic development, poverty \& natural resources GDP per capita (current US\$, 120-12,156)

Life expectancy at birth (years, 37-74)

Rural population (\% of total population, $14-95$ )

Net oil exports value per capita (constant 2000\$, -180 - 3,232)

Contextual effects: civil war

Civil war in year of election? (0-1)

Control variable: type election ${ }^{\text {a }}$

Presidential
Vote buying

\section{Election \\ administration \\ Government \\ intimidation}

$-0.144^{*}$

$0.475^{* * *}$

$0.728^{* * *}$

$0.298^{* * *}$

$-0.078+$

$0.209 * *$

$0.173^{* *}$

$0.029 * * *$

$-0.031^{* * *}$

$-0.004 * *$

0.001

$-0.019^{*}$

0.001

0.007

$-4.08 \mathrm{E}-05$

$-2.50 \mathrm{E}-05$

0.000

$-0.016^{*}$

$-0.013$

1.03E-04

$0.023^{* * *}$

1.31E-04

6.21E-06

0.005

$-0.011$

3.66E-05

0.131

0.033

$0.301 * * *$

iolence

$-0.003 *$

4.28E-05

0.003

$0.025 *$

$-9.14 \mathrm{E}-05$ 


$\begin{array}{lllll}\text { Concurrent } & 0.169 * & -0.091 & -0.045 & 0.038 \\ \text { Constant } & 4.191 * * * & 0.521 & -1.062 & -1.201 \\ \text { R-squared (within) } & 0.48 & 0.6 & 0.44 & 0.27 \\ \text { N level 1 (elections) } & 214 & 214 & 214 & 184 \\ \text { N level 2 (countries) } & 32 & 32 & 32 & 32\end{array}$

Time series cross-section analyses, fixed effects. P-values: $+0.1, * 0.05, * * 0.01, * * * 0.001$. (two-sided). a. Legislative is reference category. 